\title{
Amyloid pathology in the brain after ischemia
}

\author{
Ryszard Pluta ${ }^{1}$, Marzena Ułamek-Kozioł ${ }^{1,2}$, Sławomir Januszewski ${ }^{1}$, Stanisław J. Czuczwar ${ }^{3}$ \\ ${ }^{1}$ Laboratory of Ischemic and Neurodegenerative Brain Research, Mossakowski Medical Research Centre, Polish Academy \\ of Sciences, Warsaw, Poland, ${ }^{2}$ First Department of Neurology, Institute of Psychiatry and Neurology, Warsaw, Poland, ${ }^{3}$ Department \\ of Pathophysiology, Medical University of Lublin, Lublin, Poland
}

\begin{abstract}
As the population is aging all over the world, the economic burden of ischemic brain injuries is constantly increasing. Human brain ischemia is one of the leading causes of premature death, significant morbidity and physical and mental disabilities, resulting in a lower quality of life and unusually high costs of health and social care. One of the most difficult problems associated with the pathology of the brain after ischemia is progressive dementia observed in people who survived the stroke. More recently, brain ischemia has been shown to elicit Alzheimer's disease neuropathologic change, possibly facilitating the development of dementia due to the amyloidogenic processing of Alzheimer's disease-related amyloid protein precursor into amyloid. The main purpose of this review is to present the development of Alzheimer's disease neuropathologic change in the brain after human and experimental ischemia, with a particular emphasis on proteins and genes involved in the amyloidogenic processing of the amyloid protein precursor to amyloid.
\end{abstract}

Key words: brain ischemia, ischemic stroke, amyloid protein precursor, amyloid, $\beta$-secretase, presenilin 1, presenilin 2 , cognitive decline, dementia, protein, gene.

\section{Introduction}

Brain ischemia is more and more common in aging societies in both developing and developed countries. Ischemic stroke is the second cause of death and the third cause of disability and may soon become the leading cause of death in the world $[6,10,39]$ and the development of the Alzheimer's disease $[9,20,28,38,73]$. Epidemiological research indicates that approximately 17 million patients are diagnosed with an ischemic stroke each year [6,9]. About 6 million stroke patients die every year around the world [6]. Currently, the number of patients who survived ischemic stroke has reached 33 million $[6,9]$. According to epidemiologi- cal forecasts, this number will increase to 77 million in 2030 [6]. Physical damage after the stroke usually improves to a greater or lesser extent, but for unknown reasons, the decline in cognitive activity is slowly progressing. Recent reports on the burden of ischemic stroke in relation to incidence, prevalence, disability-adjusted life-years loss, loss of work efficiency, dependence in daily life activities and mortality have shown a growing economic burden with regard to the high costs of health and social care and clinical practice of people who suffered a stroke [16-18]. Information on the increased incidence of ischemic stroke in 18-50-year-old patients which has been recently released indicates that the incidence of stroke in adults is more than 2 million 
cases per year [5]. Therefore, it should not come as a surprise that cognitive impairment due to injury after the stroke, which eventually turns into dementia, accounts for a significant part of the costs related to health care, clinical practice and social services. The total annual cost of an ischemic stroke in Europe was around 64 billion euros in 2010 [42]. The occurrence of dementia after the first stroke is estimated at $10 \%$ of survivors and after recurrent stroke at 33-41\% [44]. In a long-term study on the incidence of stroke-related dementia, cumulative incidence over 25 years was estimated at 48\% [32]. Other authors argue that if the trend of problems with ischemic stroke continues, by 2030 about 12 million people will die, 70 million people will be after a stroke and more than 200 million disability-adjusted life-years loss will be noted annually worldwide [18]. It has been shown that focal cerebral ischemia in humans, caused by unilateral carotid stenosis, causes an increased accumulation of amyloid in the brain confirmed by positron emission tomography, which suggests a relationship between ischemic stroke and Alzheimer's disease-related amyloid [23]. Data from experimental studies have shown that the presence of a high level of amyloid in the brain after ischemia increases the neuroinflammatory response and the size of the infarct $[77,83,87]$. The aim of this review is to present the generation of amyloid in the brain after human and experimental ischemia, with a particular emphasis on proteins and genes involved in amyloidogenic processing of the amyloid protein precursor to amyloid.

\section{Amyloid in brain and blood after brain ischemia}

\section{In humans}

In the human brain after ischemia, amyloid accumulation in various brain structures has been demonstrated $[26,27,37,88]$. Observations have shown both diffuse and senile amyloid plaques in areas of the brain prone to ischemia, in the cerebral cortex and in arterial border zones after brain injury due to ischemia and reperfusion $[26,27,37,88]$. The amount of amyloid plaques in various areas of the brain correlated well with the age of the patient who had an ischemic event [26,27]. In addition, in the white and grey matter, immunological staining of amyloid in the perivascular space that surround- ed the vessels was found [88]. The accumulation of amyloid in the perivascular space looked like cuffs. Amyloid deposits in the perivascular space of the blood-brain barrier microvessels suggest that amyloid originated from serum $[48,52,53,56]$. Evidence confirming this idea comes from a clinical study in which plasma amyloid is found to be elevated (approximately a 70-fold increase) in patients after a brain ischemia-reperfusion episode [33,91]. Neurons from the hippocampus and cortex were very strongly stained on amyloid. Epithelial and ependymal cells also stained on the amyloid. In the cells of the choroid plexus, epithelium and the lining cells bordering the cerebral ventricles, the receptor for advanced glycation end-products was found [37]. The data showed that the choroid plexus epithelium and the lining cells, equipped with a receptor for advanced glycation end products, play not only a significant role in the accumulation of amyloid in brain tissue, but also are a place where amyloid can be removed [52,53]. According to another research article, the immunoreactivity of amyloid 1-40 and 1-42 in the human hippocampus after ischemia was observed in the intra- and extracellular space [74].

\section{In animals}

Various parts of the amyloid protein precursor have been reported in the intra- and extracellular space of the hippocampus, white matter, cortex and around the lateral ventricles, after an episode of ischemia of the brain with reperfusion in animals [19,21,24,25,35,36,46,49-51,57,60,61,80,84,90]. Numerous extracellular depositions of various fragments of the amyloid protein precursor were noted around the microvessels of the blood-brain barrier. Perivascular deposits of all parts of the amyloid protein precursor formed well-marked, irregular, diffuse plaques that regularly surround the vessels and resemble a perivascular hallo or cuff [46]. Accumulation of all fragments of the amyloid protein precursor, such as $\mathrm{N}$ - and C-terminal and $\beta$-amyloid peptide, in neuronal, glial, pericyte, endothelial and ependymal cells was also observed $[2-4,41,43,46,50,54,55]$. Deposition of amyloid as diffuse plaques in response to experimental ischemia-reperfusion injury of the brain does not appear to be a temporary phenomenon because diffuse amyloid deposits have been shown to convert to the senile plaque at approximately 9 months after ischemic damage [85]. 


\section{mRNA of the amyloid protein precursor in the brain after experimental ischemia}

After experimental brain injury due to ischemia and reperfusion, the mRNA of the amyloid protein precursor was induced in penumbra and in the core, up to $200 \%$ and $150 \%$, respectively $[78,79]$. After focal ischemic brain injury with recirculation, the amyloid 751 and 770 protein precursor mRNA also increased within one week [31].

\section{mRNA of enzymes processing the amyloid protein precursor in the brain after experimental ischemia}

$\alpha$-secretase mRNA, which metabolizes the amyloid protein precursor by non-amyloidogenic processing [14], decreased after experimental brain damage due to ischemia-reperfusion [40]. In amyloidogenic processing, the amyloid protein precursor is metabolized by $\beta$ - and $\gamma$-secretase [14], whose mRNA and activity are stimulated by the ischemic episode in the cerebral cortex and the hippocampus to produce the $\beta$-amyloid peptide $[8,11,12,62,86,87]$. In other studies, the maximum increase in presenilin 1 mRNA was recorded in the hippocampus, cortex and striatum after ischemic brain injury with recirculation $[45,82]$.

\section{Genes involved in the production of amyloid in the brain after experimental ischemia}

\section{CA1 region of the hippocampus}

Expression of the amyloid protein precursor gene dropped below the control values in the CA1 hippocampal region 2 days after brain ischemia with recirculation [30]. But at that time, the expression of the $\beta$-secretase and presenilin 1 and 2 genes was maximal [30]. Expression of the amyloid protein precursor, $\beta$-secretase and presenilin 1 and 2 genes increased above the control value 7 days after ischemic brain injury [30]. Expression of the amyloid protein precursor gene increased above the control value, while the $\beta$-secretase and presenilin 1 and 2 genes decreased below control values 30 days after ischemic cerebral episode [30]. Modifications of the mean level of expression of the amyloid protein precursor, $\beta$-secretase and presenilin 2 genes were statistically significant between 2 and 7, between 2 and 30 and between 7 and 30 days after brain injury as a result of ischemia-reperfusion [30]. Changes in the mean level of expression of the presenilin 1 gene were statistically significant between 2 and 30 and between 7 and 30 days after the ischemic episode [30].

\section{Medial temporal cortex}

Expression of the amyloid protein precursor gene in the medial temporal cortex decreased below control values 2 days after cerebral ischemia with recirculation [63]. But at that time, the expression of the $\beta$-secretase gene increased maximally [63]. Seven and thirty days after ischemic brain injury, the expression of the amyloid protein precursor gene has risen above the control value, and the expression of the $\beta$-secretase gene has been reduced below the control values [63]. Expression of the presenilin 1 gene was within the control limits on days 2, 7 and 30 after brain injury by ischemia-reperfusion [64]. On the second day after ischemia, the expression of the presenilin 2 gene was maximal, but on days 7 and 30 of the recirculation the expression was within the control limits [64]. Changes in the mean level of gene expression of the amyloid protein precursor, $\beta$-secretase and presenilin 2 were statistically significant between 2 and 7 and between 2 and 30 days after brain injury due to ischemia-reperfusion $[63,64]$. Changes in the mean level of expression of the presenilin 1 gene were not statistically significant at all the time after ischemia [64].

\section{Discussion}

The presented data support the thesis that ischemia-reperfusion injury of the brain plays a key role in the amyloidogenic processing of the amyloid protein precursor to amyloid in the ischemic brain and blood [30,33,46,57,62,65,70,76,91]. The amyloid protein precursor is metabolized by $\beta$-secretase, whose gene expression $[30,65,66]$, mRNA and protein level $[12,86,89]$ increases in the brain after ischemia-reperfusion injury. Expression of presenilin genes and their levels of mRNA and proteins that are increased following ischemic brain injury $[30,40,64,82]$ are involved in the production of the $\beta$-amyloid peptide by the $\gamma$-secretase complex $[62,65]$. After brain injury due to ischemia and reperfusion, the amyloid level rises as a consequence of neuronal death after ischemia [24] and it is highly likely that neurotoxic amyloid activity additionally exacerbates ischemic neuronal damage. The above data help to understand 
acute and chronic neuronal loss and brain atrophy after the ischemia-reperfusion episode in the brain [7,20,22,54,57-59] and slow, progressive accumulation of amyloid plaques in the brain tissue after the ischemia episode $[26,27,46,57,85,88]$. After ischemic brain injury, an increase in blood amyloid levels was observed in humans $[33,91]$. The level of serum amyloid growth correlated negatively with the clinical improvement after ischemia-reperfusion brain injury, which in turn reflected the severity of ischemic injury [91] and/or the development of recurrent ischemic stroke [47]. We can conclude that the proteomic and genomic changes associated with Alzheimer's disease contribute to brain ischemia-reperfusion neurodegeneration [72] with the development of the dementia $[7,9,13,15,28,29,34,75,81]$.

Brain injury after ischemia seems to favour the development of ischemic neurodegeneration of the Alzheimer's disease neuropathologic change [1] by neuronal damage and death [54], neuroinflammation [77], accumulation of all parts of the amyloid protein precursor, especially amyloid [46,58], tau protein dysfunction $[67,68]$ and dysregulation of proteins associated with Alzheimer's disease and their genes $[30,63,64]$, changes in the white matter and general brain atrophy with final development of dementia $[66,71,75]$. Therefore, it is now required to know the mechanisms underlying the progressive development of irreversible effects in the brain after ischemia. Here we present new pathways in ischemia-reperfusion neurodegeneration with the phenotype and genotype of Alzheimer's disease, focusing on the expression of genes involved in the metabolism of the amyloid protein precursor to amyloid. Increased expression of the amyloid protein precursor and its amyloidogenic processing genes and proteins after ischemic brain damage sheds new light on a better understanding of the role of amyloid as an additional factor in neuropathology after ischemia. In addition, dysregulation of genes involved in amyloid production, such as the amyloid protein precursor, $\beta$-secretase and presenilin 1 and 2 in the hippocampus and medial temporal cortex after brain ischemia, has been documented, and these genes and proteins are important in the development of sporadic Alzheimer's disease. It has also been shown that ischemic-reperfusion injury of the brain induces neuronal damage in the hippocampus and temporal cortex in an amyloid-dependent manner $[30,63,64]$, thus determining a new and import- ant way to regulate the survival or death of neurons. Although important advances have recently been made in research on neuropathogenicity of amyloid after cerebral ischemia, the basic pathways/mechanisms induced by amyloid after ischemia with the reperfusion of irreversible neurodegeneration are still unclear. The high prevalence of dementia in survivors of ischemic stroke remains a challenge for both the scientific and the clinical community [69]. It seems clear that future research should focus on preventing the development of Alzheimer's disease neuropathologic change [1] in the brain after ischemia associated with proteins characteristic for Alzheimer's disease and their genes, which may result in better neurological outcomes after the ischemic episode.

\section{Acknowledgements}

The authors acknowledge the financial support from the following institutions: the Mossakowski Medical Research Centre, Polish Academy of Sciences, Warsaw, Poland (T3-RP) and the Medical University of Lublin, Lublin, Poland (DS 475/19-SJC).

\section{Disclosure}

The authors report no conflict of interest.

\section{References}

1. Armstrong RA. A comparison of the spatial patterns of $\beta$-amyloid $(A \beta)$ deposits in five neurodegenerative disorders. Folia Neuropathol 2018; 56: 284-292.

2. Badan I, Platt D, Kessler C, Popa-Wagner A. Temporal dynamics of degenerative and regenerative events associated with cerebral ischemia in aged rats. Gerontology 2003; 49: 356-365.

3. Badan I, Dinca I, Buchhold B, Suofu Y, Walker L, Gratz M, Platt D, Kessler CH, Popa-Wagner A. Accelerated accumulation of $\mathrm{N}$ and C-terminal beta APP fragments and delayed recovery of microtubule-associated protein 1B expression following stroke in aged rats. Eur J Neurosci 2004; 19: 2270-2280.

4. Banati RB, Gehrmann J, Wiessner C, Hossmann KA, Kreutzberg GW. Glial expression of the $\beta$-amyloid precursor protein (APP) in global ischemia. J Cereb Blood Flow Metab 1995; 15: 647-654.

5. Béjot Y, Bailly H, Durier J, Giroud M. Epidemiology of stroke in Europe and trends for the 21st century. Presse Med 2016; 45: 391-398.

6. Bejot Y, Daubail B, Giroud M. Epidemiology of stroke and transient ischemic attacks: Current knowledge and perspectives. Rev Neurol 2016; 172: 59-68.

7. Bivard A, Lillicrap T, Maréchal B, Garcia-Esperon C, Holliday E, Krishnamurthy V, Levi CR, Parsons M. Transient ischemic attack results in delayed brain atrophy and cognitive decline. Stroke 2018; 49: 384-390. 
8. Blasko I, Beer R, Bigl M, Apelt J, Franz G, Rudzki D, Ransmayr G, Kampfl A, Schliebs R. Experimental traumatic brain injury in rats stimulates the expression, production and activity of Alz heimer's disease $\beta$-secretase (BACE-1). J Neural Transm 2004. 111: 523-536.

9. Brainin M, Tuomilehto J, Heiss WD, Bornstein NM, Bath PM, Teuschl Y, Richard E, Guekht A, Quinn T; Post Stroke Cognition Study Group. Post-stroke cognitive decline: an update and perspectives for clinical research. Eur J Neurol 2015; 22: 229-238.

10. Cassella CR, Jagoda A. Ischemic stroke: Advances in diagnosis and management. Emerg Med Clin N Am 2017; 35: 911-930.

11. Chen XH, Siman R, Iwata A, Meaney DF, Trojanowski JQ, Smith $D H$. Long-term accumulation of amyloid- $\beta$, $\beta$-secretase, presenilin-1, and caspase- 3 in damaged axons following brain trauma. Am J Pathol 2004; 165: 357-371.

12. Chuang CM, Hsieh CL, Lin HY, Lin JG. Panax Notoginseng Burk attenuates impairment of learning and memory functions and increases ED1, BDNF and beta-secretase immunoreactive cells in chronic stage ischemia-reperfusion injured rats. Am J Chin Med 2008; 36: 685-693.

13. Cohan CH, Neumann JT, Dave KR, Alekseyenko A, Binkert M, Stransky K, Lin HW, Barnes CA, Wright CB, Perez-Pinzon MA Effect of cardiac arrest on cognitive impairment and hippocampal plasticity in middle-aged rats. PLoS One 2015; 10: e0124918.

14. Czubowicz K, Wójtowicz S, Wencel PL, Strosznajder RP. The role of ceramide and SEW 2871 in the transcription of enzymes involved in amyloid $\beta$ precursor protein metabolism in an experimental model of Alzheimer's disease. Folia Neuropathol 2018; 56: 196-205.

15. De la Tremblaye PB, Plamondon H. Impaired conditioned emotional response and object recognition are concomitant to neuronal damage in the amygdale and perirhinal cortex in middle-aged ischemic rats. Behav Brain Res 2011; 219: 227-233.

16. Donovan NJ, Kendall DL, Heaton SC, Kwon S, Velozo CA, Duncan PW. Conceptualizing functional cognition in stroke. Neurorehabil Neural Repair 2008; 22: 122-135.

17. Ekker MS, Boot EM, Singhal AB, Tan KS, Debette S, Tuladhar AM, de Leeuw FE. Epidemiology, etiology, and management of ischaemic stroke in young adults. Lancet Neurol 2018; 17: 790-801.

18. Feigin VL, Forouzanfar MH, Krishnamurthi R, Mensah GA, Connor M, Bennett DA, Moran AE, Sacco RL, Anderson L, Truelsen T, O'Donnell M, Venketasubramanian N, Barker-Collo S, Lawes CM, Wang W, Shinohara Y, Witt E, Ezzati M, Naghavi M, Murray C; Global Burden of Diseases, Injuries, and Risk Factors Study 2010 (GBD 2010) and the GBD Stroke Experts Group. Global and regional burden of stroke during 1990-2010: findings from the Global Burden of Disease Study 2010. Lancet 2014; 18: 245 254.

19. Fujioka M, Taoka T, Matsuo Y, Mishima K, Ogoshi K, Kondo Y, Isuda M, Fujiwara M, Asano T, Sakaki T, Miyasaki A, Park D, Siesjo BK. Magnetic resonance imaging shows delayed ischemic striatal neurodegeneration. Ann Neurol 2003; 54: 732-747.

20. Gemmell E, Bosomworth H, Allan L, Hall R, Khundakar A, Oakley AE, Deramecourt V, Polvikoski TM, O’Brien JT, Kalaria RN. Hippocampal neuronal atrophy and cognitive function in delayed post-stroke and aging-related dementias. Stroke 2012; 43: 808-814.
21. Hall ED, Oostveen JA, Dunn E, Carter DB. Increased amyloid protein precursor and apolipoprotein $\mathrm{E}$ immunoreactivity in the selectively vulnerable hippocampus following transient forebrain ischemia in gerbils. Exp Neurol 1995; 135: 17-27.

22. Hossmann KA, Schmidt-Kastner R, Grosse Ophoff B. Recovery of integrative central nervous function after one hour global cerebro-circulatory arrest in normothermic cat. I Neurol Sci 1987; 77: 305-320

23. Huang KL, Lin KJ, Ho MY, Chang YJ, Chang CH, Wey SP, Hsieh CJ, Yen TC, Hsiao IT, Lee TH. Amyloid deposition after cerebral hypoperfusion: evidenced on [(18)F] AV-45 positron emission tomography. J Neurol Sci 2012; 319: 124-129.

24. Ishimaru H, Ishikawa K, Haga S, Shoji M, Ohe Y, Haga C, Sasaki A, Takashashi A, Maruyama Y. Accumulation of apolipoprotein E and $\beta$-amyloid-like protein in a trace of the hippocampal CA1 pyramidal cell layer after ischaemic delayed neuronal death. NeuroReport 1996; 7: 3063-3067.

25. Jabłoński M, Maciejewski R, Januszewski S, Ułamek M, Pluta R. One year follow up in ischemic brain injury and the role of Alzheimer factors. Physiol Res 2011; 60 (Suppl 1): S113-S119.

26. Jendroska K, Poewe W, Daniel SE, Pluess J, Iwerssen-Schmidt H, Paulsen J, Barthel S, Schelosky L, Cervos-Navarro J, De Armond SJ. Ischemic stress induces deposition of amyloid beta immunoreactivity in human brain. Acta Neuropathol 1995; 90: 461-466.

27. Jendroska K, Hoffmann OM, Patt S. Amyloid $\beta$ peptide and precursor protein (APP) in mild and severe brain ischemia. Ann NY Acad Sci 1997; 826: 401-405.

28. Kim JH, Lee Y. Dementia and death after stroke in older adults during a 10-year follow-up: Results from a competing risk model. J Nutr Health Aging 2018; 22: 297-301.

29. Kiryk A, Pluta R, Figiel I, Mikosz M, Ułamek M, Niewiadomska G, Jabłoński M, Kaczmarek L. Transient brain ischemia due to cardiac arrest causes irreversible long-lasting cognitive injury. Behav Brain Res 2011; 219: 1-7.

30. Kocki J, Ułamek-Kozioł M, Bogucka-Kocka A, Januszewski S, Jabłoński M, Gil-Kulik P, Brzozowska J, Petniak A, FurmagaJabłońska W, Bogucki J, Czuczwar SJ, Pluta R. Dysregulation of amyloid precursor protein, $\beta$-secretase, presenilin 1 and 2 genes in the rat selectively vulnerable CA1 subfield of hippocampus following transient global brain ischemia. J Alzheimers Dis 2015; 47: 1047-1056.

31. Koistinaho J, Pyykonen I, Keinanen R, Hokfelt T. Expression of $\beta$-amyloid precursor protein mRNAs following transient focal ischaemia. NeuroReport 1996; 7: 2727-2731.

32. Kokmen E, Whisnant JP, O'Fallon WM, Chu CP, Beard CM. Dementia after ischemic stroke: a population-based study in Rochester, Minnesota (1960-1984). Neurology 1996; 46: 154-159.

33. Lee PH, Bang OY, Hwang EM, Lee JS, Joo US, Mook-Jung I, Huh K. Circulating beta amyloid peptide is elevated in patients with acute ischemic stroke. J Neurol Transm 2005; 112: 1371-1379.

34. Li J, Wang YJ, Zhang M, Fang CQ, Zhou HD. Cerebral ischemia aggravates cognitive impairment in a rat model of Alzheimer's disease. Life Sci 2011; 89: 86-92.

35. Lin B, Schmidt-Kastner R, Busto R, Ginsberg MD. Progressive parenchymal deposition of $\beta$-amyloid precursor protein in rat brain following global cerebral ischemia. Acta Neuropathol 1999; 97: 359-368. 
36. Lin B, Ginsberg MD, Busto R. Hyperglycemic but not normoglycemic global ischemia induces marked early intraneuronal expression of $\beta$-amyloid precursor protein. Brain Res 2001; 888: 107-116.

37. Maślińska D, Laure-Kamionowska M, Taraszewska A, Deręgowski K, Maśliński S. Immunodistribution of amyloid beta protein (A $\beta$ ) and advanced glycation end-product receptors (RAGE) in choroid plexus and ependyma of resuscitated patients. Folia Neuropathol 2011; 49: 295-300.

38. Mok VCT, Lam BYK, Wang Z, Liu W, Au L, Leung EYL, Chen S, Yang J, Chu WCW, Lau AYL, Chan AYY, Shi L, Fan F, Ma SH, Ip V, Soo YOY, Leung TWH, Kwok TCY, Ho CL, Wong LKS, Wong A. Delayed onset dementia after stroke or transient ischemic attack. Alzheimers Dement 2016; 12: 1167-1176.

39. Mozaffarian D, Benjamin EJ, Go AS, Arnett DK, Blaha MJ, Cushman M, Das SR, de Ferranti S, Després JP, Fullerton HJ, Howard VJ, Huffman MD, Isasi CR, Jiménez MC, Judd SE, Kissela BM, Lichtman JH, Lisabeth LD, Liu S, Mackey RH, Magid DJ, McGuire DK, Mohler ER 3rd, Moy CS, Muntner P, Mussolino ME, Nasir K, Neumar RW, Nichol G, Palaniappan L, Pandey DK, Reeves MJ, Rodriguez CJ, Rosamond W, Sorlie PD, Stein J, Towfighi A, Turan TN, Virani SS, Woo D, Yeh RW, Turner MB; American Heart Association Statistics Committee; Stroke Statistics Subcommittee. Executive summary: heart disease and stroke statistics-2016 update: a report from the American heart association. Circulation 2016; 133: 447-454

40. Nalivaeva NN, Fisk L, Kochkina EG, Plesneva SA, Zhuravin IA, Babusikova E, Dobrota D, Turner AJ. Effect of hypoxia/ischemia and hypoxic preconditioning/reperfusion on expression of some amyloid-degrading enzymes. Ann NY Acad Sci 2004; 1035: 21-33.

41. Nihashi T, Inao S, Kajita Y, Kawai T, Sugimoto T, Niwa M, Kabeya R, Hata N, Hayashi S, Yoshida J. Expression and distribution of beta amyloid precursor protein and beta amyloid peptide in reactive astrocytes after transient middle cerebral artery occlusion. Acta Neurochir 2001; 143: 287-295.

42. Olesen J, Gustavsson A, Svensson M, Wittchen HU, Jonsson B, on behalf of the CDBE2010 study group and the European Brain Council. The economic cost of brain disorders in Europe. Eur J Neurol 2012; 19: 155-162.

43. Palacios G, Mengod G, Tortosa A, Ferrer I, Palacios JM. Increased $\beta$-amyloid precursor protein expression in astrocytes in the gerbil hippocampus following ischaemia: association with proliferation of astrocytes. Eur J Neurosci 1995; 7: 501-510.

44. Pendlebury ST, Rothwell PM. Prevalence, incidence, and factors associated with pre-stroke and post-stroke dementia: a systematic review and meta-analysis. Lancet Neurol 2009; 8: 1006-1018.

45. PennypackerKR, HernandezH,BenkovicS,MorganDG, WillingAE, Sanberg PR. Induction of presenilins in the rat brain after middle cerebral arterial occlusion. Brain Res Bull 1999; 48: 539 543.

46. Pluta R, Kida E, Lossinsky AS, Golabek AA, Mossakowski MJ, Wisniewski HM. Complete cerebral ischemia with short-term survival in rats induced by cardiac arrest: I. Extracellular accumulation of Alzheimer's $\beta$-amyloid protein precursor in the brain. Brain Res 1994; 649: 323-328.
47. Pluta R, Lossinsky AS, Walski M, Wiśniewski HM, Mossakowski MJ. Platelet occlusion phenomenon after short- and longterm survival following complete cerebral ischemia in rats produced by cardiac arrest. J Brain Res 1994; 35: 463-471.

48. Pluta R, Barcikowska M, Januszewski S, Misicka A, Lipkowski AW. Evidence of blood-brain barrier permeability/leakage for circulating human Alzheimer's $\beta$-amyloid-(1-42)-peptide. NeuroReport 1996; 7: 1261-1265.

49. Pluta R. Experimental model of neuropathological changes characteristic for Alzheimer's disease. Folia Neuropathol 1997; 35: 94-98.

50. Pluta R, Barcikowska M, Dębicki G, Ryba M, Januszewski S. Changes in amyloid precursor protein and apolipoprotein $\mathrm{E}$ immunoreactivity following ischemic brain injury in rat with long-term survival: influence of idebenone treatment. Neurosci Lett 1997; 232: 95-98.

51. Pluta R, Barcikowska M, Mossakowski MJ, Zelman I. Cerebral accumulation of beta-amyloid following ischemic brain injury with long-term survival. Acta Neurochir Suppl 1998; 71: 206-208.

52. Pluta R, Barcikowska M, Misicka A, Lipkowski AW, Spisacka S, Januszewski S. Ischemic rats as a model in the study of the neurobiological role of human beta-amyloid peptide. Time-dependent disappearing diffuse amyloid plaques in brain. NeuroReport 1999; 10: 3615-3619.

53. Pluta R, Misicka A, Barcikowska M, Spisacka S, Lipkowski AW, Januszewski S. Possible reverse transport of beta-amyloid peptide across the blood-brain barrier. Acta Neurochir 2000; 76 (Suppl.): 73-77.

54. Pluta R. The role of apolipoprotein $E$ in the deposition of $\beta$-amyloid peptide during ischemia-reperfusion brain injury. A model of early Alzheimer's disease. Ann NY Acad Sci 2000; 903: 324-334.

55. Pluta R. No effect of anti-oxidative therapy on cerebral amyloidosis following ischemia-reperfusion brain injury. Folia Neuropathol 2000; 38: 188-190.

56. Pluta R. Pathological opening of the blood-brain barrier to horseradish peroxidase and amyloid precursor protein following ischemia-reperfusion brain injury. Chemotherapy 2005; 51: 223-226.

57. Pluta R, Ułamek M, Jabłoński M. Alzheimer's mechanisms in ischemic brain degeneration. Anat Rec 2009; 292: 1863-1881.

58. Pluta R, Januszewski S, Jabłoński $M$, Ułamek $M$. Factors in creepy delayed neuronal death in hippocampus following brain ischemia-reperfusion injury with long-term survival. Acta Neurochir Suppl 2010; 106: 37-41.

59. Pluta R, Ułamek M, Jabłoński M. Consideration of the ischaemic basis and treatment of Alzheimer's disease. Folia Neuropathol 2010; 48: 11-26.

60. Pluta R, Jabłoński M. Alzheimer's factors in ischemic brain injury. In: Agrawal A (ed.). Brain injury, pathogenesis, monitoring, recovery and management. InTech, Open Book, Rijeka, Croatia 2012; pp. 97-138.

61. Pluta R, Ułamek-Kozioł M, Januszewski S, Ściślewska M, Bogucka-Kocka A, Kocki J. Alzheimer's factors in postischemic dementia. Rom J Morphol Embryol 2012; 53: 461-466.

62. Pluta R, Furmaga-Jabłońska W, Maciejewski R, Ułamek-Kozioł M, Jabłoński M. Brain ischemia activates $\beta$ - and $\gamma$ - secretase cleavage of amyloid precursor protein: significance in sporadic Alzheimer's disease. Mol Neurobiol 2013; 47: 425-434. 
63. Pluta R, Kocki J, Ułamek-Kozioł M, Petniak A, Gil-Kulik P, Januszewski S, Bogucki J, Jabłoński M, Brzozowska J, FurmagaJabłońska W, Bogucka-Kocka A, Czuczwar SJ. Discrepancy in expression of $\beta$-secretase and amyloid- $\beta$ protein precursor in Alzheimer-related genes in the rat medial temporal lobe cortex following transient global brain ischemia. J Alzheimers Dis 2016; 51: 1023-1031.

64. Pluta R, Kocki J, Ułamek-Kozioł M, Bogucka-Kocka A, Gil-Kulik P, Januszewski S, Jabłoński M, Petniak A, Brzozowska J, Bogucki J, Furmaga-Jabłońska W, Czuczwar SJ. Alzheimer-associated presenilin 2 gene is dysregulated in rat medial temporal lobe cortex after complete brain ischemia due to cardiac arrest. Pharmacol Rep 2016; 68: 155-161.

65. Pluta R, Ułamek-Kozioł M, Januszewski S, Czuczwar SJ. Dysregulation of Alzheimer's disease-related genes and proteins following cardiac arrest. Folia Neuropathol 2017; 55: 283-288.

66. Pluta R, Ułamek-Kozioł M, Januszewski S, Czuczwar SJ. From brain ischemia to Alzheimer-like neurodegeneration. Neuropsychiatry (London) 2018; 8: 1708-1714.

67. Pluta R, Ułamek-Kozioł M, Januszewski S, Czuczwar SJ. Tau protein dysfunction after brain ischemia. J Alzheimer's Dis 2018; 66: 429-437.

68. Pluta R, Bogucka-Kocka A, Ułamek-Kozioł M, Bogucki J, Kocki J, Czuczwar SJ. Ischemic tau protein gene induction as an additional key factor driving development of Alzheimer's phenotype changes in CA1 area of hippocampus in an ischemic model of Alzheimer's disease. Pharmacol Rep 2018; 70: 881-884

69. Pluta R, Ułamek-Kozioł M, Januszewski S, Czuczwar SJ. Platelets, lymphocytes and erythrocytes from Alzheimer's disease patients: the quest for blood cell-based biomarkers. Folia Neuropathol 2018; 56: 14-20.

70. Pluta R. Brain ischemia: Alzheimer's disease mechanisms. Nova Science Publishers, Inc. New York 2019.

71. Pluta R, Ułamek-Kozioł M. The role of degenerative pathways in the development of irreversible consequences after brain ischemia. Neural Regen Res 2019; 14: 982-983.

72. Pluta R, Ułamek-Kozioł M, Czuczwar SJ. Shared genomic and proteomic contribution to brain ischemia and Alzheimer's disease: Ischemic etiology of Alzheimer's disease. In: Pluta R (ed.). Brain ischemia: Alzheimer's disease mechanisms. Nova Science Publishers, Inc., New York 2019; pp. 209-249.

73. Portegies ML, Wolters FJ, Hofman A, Ikram MK, Koudstaal PJ, Ikram MA. Prestroke vascular pathology and the risk of recurrent stroke and poststroke dementia. Stroke 2016; 47: 2119 2122

74. Qi J, Wu H, Yang Y, Wand D, Chen Y, Gu Y, Liu T. Cerebral ischemia and Alzheimer's disease: the expression of amyloid- $\beta$ and apolipoprotein E in human hippocampus. J Alzheimers Dis 2007; 12: 335-341.

75. Reuck JD, Maurage CA, Deramecourt V, Pasquier F, Cordonnier C, Leys D, Bordet R. Aging and cerebrovascular lesions in pure and in mixed neurodegenerative and vascular dementia brains: a neuropathological study. Folia Neuropathol 2018; 56: 81-87.

76. Salminen A, Kauppinen A, Kaarniranta K. Hypoxia/ischemia activate processing of amyloid precursor protein: impact of vascular dysfunction in the pathogenesis of Alzheimer's disease. J Neurochem 2017; 140: 536-549.
77. Sekeljic V, Bataveljic D, Stamenkovic S, Ułamek M, Jabłoński M, Radenovic L, Pluta R, Andjus PR. Cellular markers of neuroinflammation and neurogenesis after ischemic brain injury in the long-term survival rat model. Brain Struct Funct 2012; 217: 411-420.

78. Shi J, Panickar KS, Yang SH, Rabbani O, Day AL, Simpkins JW. Estrogen attenuates over-expression of beta-amyloid precursor protein messenger RNA in an animal model of focal ischemia. Brain Res 1998; 810: 87-92.

79. Shi J, Yang SH, Stubley L, Day AL, Simpkins JW. Hypoperfusion induces overexpression of $\beta$-amyloid precursor protein mRNA in a focal ischemic rodent model. Brain Res 2000; 853: 1-4.

80. Sinigaglia-Coimbra R, Cavalheiro EA, Coimbra CG. Postischemic hypertermia induces Alzheimer-like pathology in the rat brain. Acta Neuropathol 2002; 103: 444-452.

81. Surawan J, Areemit S, Tiamkao S, Sirithanawuthichai T, Saensak S. Risk factors associated with post-stroke dementia: a systematic review and meta-analysis. Neurol Int 2017; 9: 7216.

82. Tanimukai H, Imaizumi K, Kudo T, Katayama T, Tsuda M, Takagi T, Tohyama M, Takeda M. Alzheimer-associated presenilin-1 gene is induced in gerbil hippocampus after transient ischemia. Mol Brain Res 1998; 54: 212-218.

83. Thiel A, Cechetto DF, Heiss WD, Hachinski V, Whitehead SN. Amyloid burden, neuroinflammation, and links to cognitive decline after ischemic stroke. Stroke 2014; 45: 2825-2829.

84. Tomimoto H, Akiguchi I, Wakita H, Nakamura S, Kimura J. Ultrastructural localization of amyloid protein precursor in the normal and postischemic gerbil brain. Brain Res 1995; 672: 187195.

85. Van Groen T, Puurunen K, Maki HM, Sivenius J, Jolkkonen J. Transformation of diffuse beta-amyloid precursor protein and beta-amyloid deposits to plaques in the thalamus after transient occlusion of the middle cerebral artery in rats. Stroke 2005; 36: 1551-1556.

86. Wen Y, Onyewuchi O, Yang S, Liu R, Simpkins JW. Increased beta-secretase activity and expression in rats following transient cerebral ischemia. Brain Res 2004; 1009: 1-8.

87. Whitehead SN, Cheng G, Hachinski VC, Cechetto DF. Progressive increase in infarct size, neuroinflammation, and cognitive deficits in the presence of high levels of amyloid. Stroke 2007; 38: 3245-3250.

88. Wiśniewski HM, Maślińska D. Beta-protein immunoreactivity in the human brain after cardiac arrest. Folia Neuropathol 1996; 34: 65-71.

89. Ye J, Pi R, Mao X, Chen X, Qin J, Xu S, Liu P. Alterations in mRNA expression of BACE1, cathepsin B, and glutaminyl cyclase in mice ischemic brain. NeuroReport 2009; 20: 1456-1460.

90. Yokota M, Saido TC, Tani E, Yamaura I, Minami N. Cytotoxic fragment of amyloid precursor protein accumulates in hippocampus after global forebrain ischemia. J Cereb Blood Flow Metab 1996; 16: 1219-1223.

91. Zetterberg H, Mörtberg E, Song L, Chang L, Provuncher GK, Patel PP, Ferrell E, Fournier DR, Kan CW, Campbell TG, Meyer R, Rivnak AJ, Pink BA, Minnehan KA, Piech T, Rissin DM, Duffy DC, Rubertsson S, Wilson DH, Blennow K. Hypoxia due to cardiac arrest induces a time-dependent increase in serum amyloid $\beta$ levels in humans. PLoS One 2011; 6: e28263. 